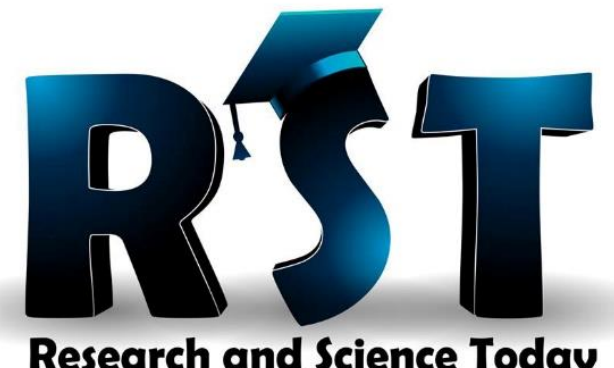

\title{
Research and Science Today
}

WWW.RSTJOURNAL.COM

\section{DOI:}

Title: CONSIDERATIONS REGARDING THE SECURITY EQUATION DETERMINED BY THE PROBLEMATICS OF REFUGEES IN THE MIDDLE EAST

Authors:

Cătălin PEPTAN

Section: INTERNATIONAL RELATIONS

Issue: $\quad 1(19) / 2020$

Received: 27 December 2019

Revised: 15 January 2020 / 5 February 2020

Accepted: 10 March 2020

Available Online: 15 March 2020

Paper available online HERE 


\title{
CONSIDERATIONS REGARDING THE SECURITY EQUATION DETERMINED BY THE PROBLEMATICS OF REFUGEES IN THE MIDDLE EAST
}

Cătălin PEPTAN ${ }^{1}$

\begin{abstract}
:
THE AUTHOR ADDRESSES A TOPICAL ISSUE AT EUROPEAN LEVEL, NAMELY THE EVOLUTION OF THE SECURITY EQUATION AT THE CONTINENTAL LEVEL DETERMINED BY THE NEW WAVE OF REFUGEES FROM THE MIDDLE EAST. IN ORDER TO UNDERSTAND THE PHENOMENA ASSOCIATED WITH THE PROBLEM, WE REVIEW THE SECURITY CLIMATE IN THE MIDDLE EAST AT THE END OF THE TWENTIETH CENTURY AND THE BEGINNING OF THE TWENTY-FIRST CENTURY, MAINLY DETERMINED BY THE MANIFESTATION OF AN INCREASING HOSTILITY OF NATIONALISM AND THAT CONECTED WITH ARABIA, AGAINST THE SERIOUS PROBLEMS, WITH DIFFERENT CAUSALITY, WHICH ARE FOUND IN MOST COUNTRIES IN THE REGION, WHICH HAVE POTENTIATED THE TERRORIST PHENOMENON, AFFECTING THE ECONOMIC AND SECURITY OF MANY STATES IN THE REGION AND GENERATING A NEW SECURITY THREAT, RESPECTIVELY THE PHENOMENON OF ILLEGAL MIGRATION OF IMPORTANT GROUPS PEOPLE OF ISLAMIC RELIGION TO THE WESTERN COUNTRIES OF THE OLD EUROPEAN CONTINENT.

THE AUTHOR ADDRESSES THE ISSUES WICH ARISES FROM THE RECENT DECISIONS OF THE AUTHORITIES IN ANKARA TO OPEN NATIONAL BORDERS TO ALLOW REFUGEES ON THE TERRITORY OF TURKEY TO TRAVEL TO DESTINATIONS IN THE EUROPEAN UNION, DOING A GEOPOLITICAL ANALYSIS OF THE CAUSES THAT HAVE GENERATED THE STATE OF AFFAIRS, OF THE MEASURES THAT ARE REQUIRED IN ORDER TO MANAGE THE SITUATION AND THE POSSIBLE CONSEQUENCES IN SECURITY AT EUROPEAN LEVEL.
\end{abstract}

KEY WORDS: TERRORISM, GLOBALIZATION, CRIME, MIGRATION, REFUGEE, THREAT, SECURITY.

\section{GENERAL CONSIDERATIONS REGARDING THE MIDDLE EAST}

The Middle East, historically speaking, has always been characterized by instability and unpredictability - a fact that has led specialists to often consider it a ,volcano in activity of geopolitics (...) whose uninterrupted eruptions (...) destabilizes the region (...) and makes it the most virulent outbreak of religious, civil and/or interstate and terrorist wars "2, and viewed from a cultural, economic and political perspective, it is a geographical area of geopolitical interference with an exceptional strategic significance, which represents the

\footnotetext{
${ }^{1}$ Lecturer, „Constantin Brâncuși” University Târgu Jiu

${ }^{2}$ Pascal, Lamy, Nicole, Gnesotto, Jean-Michel Baer, Where is the world going ?, (Bucharest: Niculescu Publishing House, 2018), 105.
} 


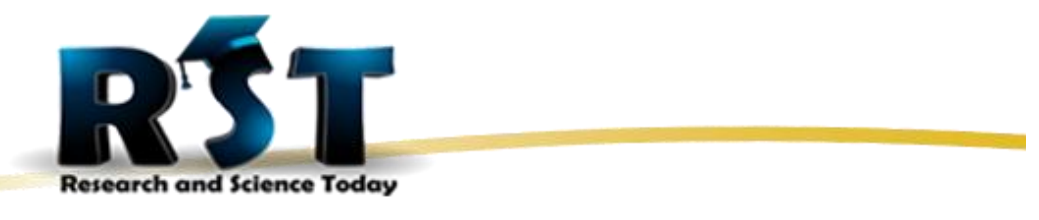

intersection of the political interests of the current world powers. ${ }^{3}$

The end of the twentieth century and the beginning of the 21 st century ${ }^{4}$ was marked by the deterioration of the security climate in the Middle East, the main cause being what we generically call the end of the bipolar international order and the transition to the ,new multipolar international order", although much the clamored creation, with the support and direct involvement of the great global powers, of the "New Middle East" fails to solve the historical problems that the region continues to face ${ }^{5}$.

Therefore, we are witnessing an increasing hostility of nationalism and pan-Arabism, which has caused many Muslims to return to the original Islam, to radical instrumentalized militantism, often from political Islam ${ }^{6}$ characterized by an exceptional social mobilization potential, explainable by the toxic mix between politics and religion, but also by not accepting the stakes of modernization and the values of Western democracy, Islamism is still the foundation of civilization of the same name, expanding on the same multisecular principles. These realities were determined by multiple causes, such as: the policies of authoritarian-totalitarian regimes that violated citizens' rights and freedoms; non-performing governance marked by corruption; the slow pace of economic development, with direct consequences on rising unemployment and inflation; widening the gap between the poor and the rich; population growth, lack of education and lack of young people's perspective of a normal life. ${ }^{7}$ The reactions of the government authorities, in many countries of the Middle East, to the unresolved social problems, generated extreme protest movements, which affected the socio-economic life and the security of the region. At the same time, they have generated the favorable context of the reappearance and manifestation of terrorism, with a new proteiform morphology, enhanced, more than ever, by the rigor and incisiveness of ideologies with great non-cultural capacity, even if they are not characterized by an ideological or normative corpus that will explain to the followers the reality and/or the social rules, well known being the fact that terrorism is nourished by a real ,hate incubator”, which has contextualizing elements of social, economic, political and cultural nature. ${ }^{8}$

Terrorism in the Middle East has gained, over the last decade ${ }^{9}$, the valence of a phenomenon, with "diffusion" tendencies to other geographical areas in nearby Africa, old Europe or far America, transforming some regions of the world into a true modern jungle, in which the criminals have no rule knowing only to kill, although, at the end of 2017, the Iraqi authorities announced the ,end of the war against the Islamic State” and the destruction of the group and ${ }^{10}$, in March 2019, the Syrian authorities announced that "Syrian democratic forces

\footnotetext{
${ }^{3}$ Cătălin, Peptan, Terrorism. Events and developments in the hot areas of the world. Middle East. Asia. Africa, (Târgu Jiu: Academica Brâncuși Publishing House, 2019), 53.

${ }^{4}$ Flavius Cristian Marcau, Mihaela Andreea Ciorei, "The vision about international security at the biggining of the XXI century", in European Scientific Journal, april 2013 edition vol.9, no.11, 301-311

${ }^{5}$ Flavius Cristian Mărcău, Mihaela Andreea Ciorei, "The role of intelligence in the fight against terror," in European Scientific Journal, IX (2013), no. 2, p. 1-11

${ }^{6}$ Anoushiravan, Ehteshami, Globalization and Geopolitics in the Middle East Old Games, New Rules, (London, Routledge, 2007), 90.

${ }^{7}$ Cătălin, Peptan, Terrorism. Events and developments in the hot areas of the world..., 55-56

${ }^{8}$ Serkan, Tasgin, Taner, Cam, „Reasons for Terrorism in the Middle East”, în Alexander R. Dawoody (editor), Eradicating Terrorism from the Middle East Policy and Administrative Approaches, Springer, 2016, pg. 86.

${ }^{9}$ Flavius Cristian Mărcău, Mihaela Andreea Ciorei, The role of intelligence in the fight against terror..., 1-11

${ }^{10} \mathrm{https} / / / \mathrm{www} . z i a r e . c o m / i n t e r n a t i o n a l / s t a t u s-i s l a m i c / 2017$-anul-prabusirii-califat-statul-islamic-1495057/ accessed 18.09.2019.
} 
declare total elimination of the so-called caliphate and $100 \%$ territorial defeat of ISIS $" 11$. In this context, the arab world has become a real ,theater of military operations" that has deeply affected the economic and security situation of many states in the region, generating a new security threat, respectively the phenomenon of illegal migration of important groups of people of Islamic religion, to the Western countries of a old European continent.

\section{THREATENING OF ILLEGAL MIGRATION - THE "WEAPON" IN THE MIDDLE EAST}

The wave of migrants from the countries of the Middle East, followers of the Islamic religion, which overturned Western Europe in the second half of the past decade, represents the climax of a broader process that has been steadily unfolding since the end of the second world conflagration, currently constituting, one of the potential sources of conflict between the Christian and the Muslim civilization, respectively between the two societies, Christian and Muslim, which are in a relationship ,continuously deep in conflict (...), intense rivalry and hectic war of different degrees". ${ }^{12}$

Serious economic, social and political problems in countries such as Syria, Iran, Iraq or Afghanistan are at the origin of waves of migrants leaving their country of origin and leaving for the unknown, looking for a job and a new home. for the young and their large family, where religious life heats, towards an aging Europe, preoccupied to renounce its origins, to detach from Christianity and to appear as a secular one.A first temporary destination is Turkey, since there are no alternative options for the migrant groups in the countries mentioned, taking into account the political and economic particularities of the countries of the Middle East or the official positions of the authorities of the western countries and of the civil society which, through various mechanisms, resort to practices of deterring and harassing migrants. ${ }^{13}$ Although Turkey is considered ,an island of peace in the region in which it is located, because it is a shelter and conscience of humanity"14 and praises its role as the „,core state” of Islamic civilization ${ }^{15}$, the recent military incursions of the Turkish army since October 2019, from northern Syria, known under the generic name of "Peace Spring", with the stated purpose of eliminating terrorist elements in the border area ${ }^{16}$, worsened the security situation in the region, with more and more important voices saying that any plan to appease the social and political system and to keep peacein the Middle East must be designed in accordance with the geo-security profile of the region. ${ }^{17}$

The increase of the Turkish-Syrian conflict, with support from Turkish authorities ${ }^{18}$ of Islamist rebels in northern Syria's Idlib region, in the fight against Syrian President Bashar al-Assad's armed forces, followed by their retaliatory measures in February 2020, reinforces

\footnotetext{
${ }^{11} \mathrm{https}: / / \mathrm{www}$. adevarul.ro/international/in-lume/statului-islamic-ras-fata-pamantului-siria1_5c95ec51445219c57e9038d4/index.html; accessed 15.11.2019.

${ }^{12}$ Samuel, Huntington, Clash of Civilizations and the Restoration of the World Order, (Bucharest: Litera Publishing House, 2019), 383.

${ }^{13}$ https://www.trt.net.tr/romana/programs/2019/07/30/turcia-si-migratia-ieri-astazi-maine-1245110/accessed 07.03.2020., point of view expressed by prof.dr . Kudret BÜLBÜL, Dean of the Faculty of Political Science at Yildirim Beyazid University in Ankara.

${ }^{14}$ https://www.trt.net.tr/romana/programs/2019/07/30/turcia-si-migratia-ieri-astazi-maine-1245110/accessed 07.03 .2020

${ }^{15}$ Samuel, Huntington, Clash of Civilizations and the Restoration of the World Order, 327-328.

${ }^{16}$ Kurdish militias and ISIS cells, motivated by the need to "restore peace and peace in Syria".

${ }^{17}$ Ece Temelcura, Turkey, between madness and melancholy, Corint Books, Bucharest, 2017, pp. 259-261.

18 According to authorities, Turkey wants to create a buffer zone in which to surround the approximately 3.5 million Syrian refugees currently in its territory.
} 
the security equation in the East it creates and creates the premises for a large military confrontation, if we analyze in depth the nature of this conflict, the causes of its escalation and the risks it generates at the regional level. In fact, Sunni Turkey re-Islamized under President Erdoğan's „hidden Islamist agenda, concealed under pro-European discourse"19, backs Sunni Islamist forces in the region, while Syrian authorities, backed by Shiite allies in Iran and Russia, appear to be victorious in the civil war in Syria.

In context, despite international agreements, which regulate the issue of refugees on the territory of Turkey, to which it is a part, the authorities in Ankara declared, during February 2020, that the conflict in the Idlib region would not be resolved and that the Syrian army's attacks on military Turkish capabilities would cease. Turkish military will determine to open the borders of Syrian refugees in Turkey so that they can move to destinations in western Europe, the ruling party in Ankara declaring that "our refugee policy is the same, but here we have a serious situation. we can keep them in place". ${ }^{20}$ Also worth mentioning are Turkey's intentions, expressed at the end of 2019, for the repatriation of ISIS fighters detained in Turkish prisons, on the grounds that „Turkey is not a tourist hotel” ${ }^{21}$. This creates the premises for a new wave of migrants to destinations in the western part of the European continent, including elements that belong to or embrace ideologies and conceptions specific to terrorist groups, if we consider that, according to the authorities in Ankara on Turkish territory over 3.6 million Syrian refugees and other nationalities are cantoned, who refuse to return to their native country, their supreme goal being the joy of freedom in a western country where they enjoy the respect of citizens' rights and have real chances to a prosperous, free and respectable life.

\section{ROAD TO EUROPE - A RISK TAKEN BY THE ACTORS INVOLVED}

The first day of the calendar spring of 2020 was marked by an avalanche of news from news agencies in Europe and the Middle East, which were announcing the statements of Turkish Minister of Internal Affairs, Suleyman Soylu, according to which Turkey would open in Edirne the crossing points, of the border to Greece and Bulgaria, allowing 76,385 Syrian refugees to move to European Union countries, at the same time, threatening to allow a new influx of Syrian refugees to pass if they do not get concrete support from international bodies in the conflict in northern Syria ${ }^{22}$. It is worth noting that Turkey has motivated these decisions by the inability to cope with a new wave of Syrian refugees from the Idleb region, following the offensive launched by the Damascus authorities.

\footnotetext{
${ }^{19}$ Carmen Gavriluță, Revolt of the Orient, (Iași: Polirom Publishing House, 2013), 257.

${ }^{20} \mathrm{https}: / /$ www.dw.com/en/extraordinare-nato-după-escaladarea-sitiei-din-siria/a-52572751/ accessed 08.03.2020.

${ }^{21} \mathrm{https} / / / \mathrm{www} . \mathrm{dw} . c o m / \mathrm{en} / \mathrm{commentary}$-game-of-puters-in-the-supporters-isis-repatriators/a-51213795/accessed 19.11.2019.

${ }^{22} \mathrm{https} / / / \mathrm{www}$.digi24.ro/stiri/actualitate/turcia-sustine-ca-a-lasat-75-000-de-migranti-sa-treaca-frontiera-cu-ueharta-cu-traseul-refugiatilor- passing-through-the-middle-of-Romania-1268534 / accessed 08.03.2020.
} 


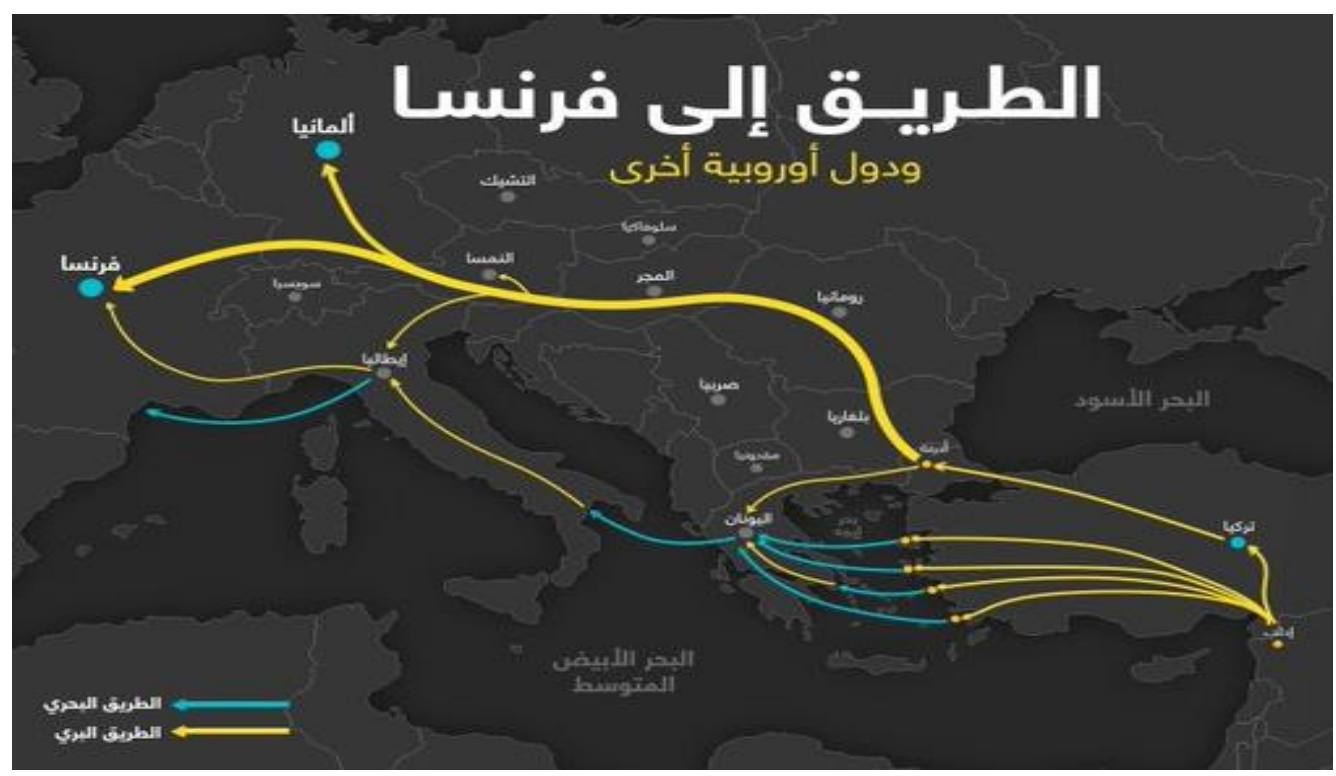

Figure 1. Syrian refugee travel routes

In the context, Turkish news agencies ${ }^{23}$ have published the map of possible Syrian refugee travel routes (figure 1) from the Syrian province of Idlib, estimated at around one million, to Western Europe, listing Greece, Bulgaria, Romania and Hungary as transit countries to the final destination.

So far, an alarming situation, regarding the refugee crisis, has been found in the Greek island of Lesbos, the geographical area considered the traditional host of refugees since the 1990s, when they came mainly from the former Yugoslavia, the scene of an abominable civil war. Today, the large number of refugees, encamped in specially equipped camps, have led human rights activists to report that the situation on the islands of Lesbos, Chios and Samos has become unbearable for both locals and immigrants, and that coherent measures should be taken to managing the situation. ${ }^{24}$ Considered to be just transit locations, within a time horizon that cannot be estimated with certainty, the Greek islands will be left by refugees who, in their quest to reach Western Europe, have as an alternative variant the Italian peninsula, the geographical area marked by the COVID -19 epidemic, which caused the Italian authorities to take the army out into the street in order to „hermetize" the entire national territory. Against this background it is almost certain that the Italian authorities will not allow the penetration of waves of migrants on the national territory that could further affect the social problems that characterize the peninsula, as they have to look for other possibilities to reach the final destination.

Another variant of displaced refugees currently on the territory of Turkey, upheld by the media from Ankara, also includes the territory of Romania, which requires the adoption by the national authorities of pragmatic response strategies, able to reduce the threats to our country and to generate, internationally, the image of a security exporting state and not a generator of security risks. This scenario reconfirms the idea conveyed during the migration crisis of 2014-2016, according to which Romania, although not traditionally confronting with

\footnotetext{
${ }^{23} \mathrm{https}: / /$ www.english.alarabiya.net/en/media/television-and-radio/2020/02/29/Turkish-state-owned-TRTArabic-posts-map-showing-refugees-path-to- France.html? Fbclid = IwAR3uEyzE4WhiN4teDjgItlgg0HYCcXbhxFPDB0WAjmYPmowbRzE36jjMR5M / accessed 08.03.2020. ${ }^{24} \mathrm{https}: / / \mathrm{www} . d w . c o m / e n / c r i z a-r e f u g i a a t i i-i n-g r e c i a-s i t u i t a t e a-s e-a g r a v a t a ̆-p e l e s b o s / a-52605453 / a c c e s s e d$ 08.03.2020.
} 


\section{RST}

a significant number of illegal migration cases, is a transit area preferred by organized crime groups specialized in illegal migration. In this way, risk factors and vulnerabilities for the security of Romania can be generated, such as: non-compliance with the specific legislation of border crossing and difficulty in identification of migrants; infiltration of terrorist elements or organized crime into migrant groups; dissemination on the national territory of biological risk factors that can affect the health of the population and last but not least affect the national budget by allocating additional human and material capacities necessary for the optimal management of migrants (accommodation and feeding costs of migrants, expenses with medical assistance, providing translators in refugee camps, costs related to community integration, etc.). On this issue, the former president of Romania, Traian Basescu, recently stated that Romania is not prepared to face a migratory flow and that the possible consequences in the secutary plan of entering their national territory can be disastrous.

Regardless of the travel route targeted by the refugees, in their efforts to move to western Europe, the reactions of the affected European states have been strong, especially in the context in which Turkey has signed with the European Union an agreement ${ }^{25}$ that undertakes to control the flows illegal migrants, in exchange for receiving funds and accelerating the process of joining the Union.

If, in the middle of the last decade, Germany, aged and with a large labor deficit, has opened its gates and received about one million migrants, today Chancellor Angela Merkel considers unacceptable the ,pressure put by Turkey on the European Union” by opening border points on the border with Greece and is opposed to receiving a new wave of refugees on the territory of Germany, which would fuel the revival of the extreme right and would worsen the internal security equation. ${ }^{26}$ The solution proposed by the German Chancellor refers to the observance of the agreement concluded in 2016 between the European Union and Turkey aimed at obstructing the movement of migrants to western Europe.

On the other hand, the President of France, Emanuel Macron for avoiding a humanitarian crisis caused by the problems of migrants in Turkey, urging joint European efforts to help quickly and to protect the borders of Greece and Bulgaria. A similar view was also expressed by the President of the European Commission, Ursula von der Leyen, who announced that the European Union will support Greece and Bulgaria through Frontex at land borders $^{27}$, intending to determine the management of the problem at the level of state entities in the vicinity of the area. cantoning them. The position of the Austrian Chancellor Sebastian Kurz recommends solidarity with regard to convergent actions to strengthen the protection of the external borders of the European Union, in order to prevent the recurrence of a migrant crisis on the European continent similar to the one of the previous decade.

A realistic approach to the issues under discussion belongs to MEP Traian Băsescu, who proposes to the international community three essential elements for managing the phenomenon of illegal migration, namely: the signing by the European Union of readmission agreements with the countries of origin of migrants, the establishment by the European Union Collaboration agreements with the authorities of the countries of transit to counter the networks of organized cross-border crime involved in the trafficking of illegal migrants and the surveillance of the traffic on the North Coast of Africa or the East Mediterranean towards

\footnotetext{
${ }^{25}$ Through the agreement concluded in 2016, the European Union has committed to grant Turkey 6 billion euros, of which 3.2 billion have been paid so far.

${ }^{26} \mathrm{https}$ ://24-ore.ro/2020/03/02/angela-merkel-declara-ca-este-inacceptabil-ca-turcia-sa-faca-presiuni-asupra-uepe-spatele-refugiatilor/ accessed 08.03.2020.

${ }^{27} \mathrm{https}$ ///www.news.ro/externe/franta-deplin-solidara-cu-grecia-si-bulgaria-afirma-macron-care-vrea-sa-se-eviteo-criza-umanitara-si-a-migratiei-in-urma-unui-aflux-de-migranti-din-turcia-1922401302002020031319286947.
} 
Greece, by the military fleets deployed in the Mediterranean and in the return to the territorial waters of countries of origin of vessels having migrants on board. ${ }^{28}$

The key to resolving the created crisis lies in the negotiations between Vladimir Putin and Recep Tayyip Erdogan, the leaders of the anti-democratic and anti-Western regimes in Moscow and Ankara, ,conjuncture allies” who often claim good relations ${ }^{29}$ despite Turkey's status as a NATO member state. Important is position of the US Department of State for Turkey's support and the imperative call for the immediate cessation of the offensive launched by Syria, Russia and the combat groups supported by Iran, or the solidarity expressed by NATO, through the voice of the alliance's secretary general, Jens. Stoltenberg. ${ }^{30}$

A possible solution to the refugee crisis in the Middle East countries, currently located in the territory of Turkey, is their integration into the Turkish society itself, given the labor shortage $^{31}$ and the problems of the national economy where the purchasing power is affected by the high level of inflation and foreign investments collapsed by $30 \%$ in 2019 . The possibility of absorbing a significant part of the refugees from the rich countries of the Arabian peninsula is also not to be neglected, a possible destination being Saudi Arabia, the country having the status of "financial superpower" ${ }^{32}$ involved in various mutual assistance programs worldwide, on the territory where there are about five million foreigners, many of them being Western citizens engaged in activities subsequent to oil extraction and refining, with possibilities of absorption of the labor force in the field. Therefore, the conditions for maintaining large groups of refugees in geographical areas belonging to the same civilization would be created, which would ensure optimal conditions for reintegration into the refugee society.

\section{CONCLUSIONS. POSSIBLE SECURITY CONSEQUENCES FOR THE EUROPEAN CONTINENT CAUSED BY MIGRATION}

The realities of the contemporary world show us the spectrum of Islamization of Western Europe, under the pressure of the Islamic society that is pulsating with religious life and is constantly expanding, is more current than ever, in the context of the voluntary secularization established with the acceptance of the social contract between man and the secular authority, proposed by the French philosopher Jean Jaques Rousseau, when society became preoccupied mainly with respect for human rights, the Christian religion being held in its private sphere and being in a continuous regress.

Western Europe is currently facing serious demographic problems, is aging and has a substantial labor shortage, and „the European Union needs migrants due to negative births”, provided, however, that migration „,is a legal one, good” quality, numerically controlled and capable of integrating into the cultural and social values of Europe" ${ }^{\prime 3}$. The level of economic

\footnotetext{
${ }^{28} \mathrm{https}$ //www.europarl.europa.eu/doceo/document/CRE-9-2020-02-12-INT-3-564-0000_RO. / accessed 09.03.2020.

${ }^{29}$ https://www.dw.com/en/in-drum-spre-un-nou-război-ruso-turc/a-52574097 The head of Turkish diplomacy, Mevlut Cavusoglu, argued that "bilateral strategic relations with Russia" would be "unshakable" / accessed 08.03.2020.

${ }^{30} \mathrm{https} / / /$ www.dw.com/ro/reuniune-extraordinară-nato-după-escaladarea-situaţiei-din-siria/a-52572751/accessed 08.03.2020.

$31 \mathrm{https} / / /$ www.business24.ro/articles/forta+munca+turcia/acceesse 09.03.2020/see the Manpower Group 2018 study.

${ }^{32}$ Peter Mansfield, A History of the Middle East, (Bucharest: Humanitas Publishing House, 2015), 303.

33 See https://www.epochtimes-romania.com/news/basescu-o-noua-interventie-in-parlliament-european-ce-zicede-migratia-ilegala-care-continua-in-ue---297146 / accessed 09.03.2020 / point of view expressed by the former President of Romania, Traian Basescu, in the work of the European Parliament.
} 


\section{R5I}

development and the concern for ensuring and respecting the fundamental human rights and freedoms, make this geographical area a favorite destination for migrants from the Arab area. Because they value different notions such as money, work, freedom, value, social coexistence, migrants are often regarded as social heretics, unintelligible in the Euro-Atlantic world, and the standards of Western life seem to be in permanent contradiction with the Koranic precepts, almost impossible. to be abandoned by their great mass. In this context, Western Europe is subject to the danger of changing its demographic and religious weight as a result of mass migration of groups of Islamic populations, with irreversible effects on everything that characterizes Western civilization.

Potential waves of Islamist migrants are perceived as a real threat to what is considered „modus vivendi occidentalis”, because „Islam has been a sword religion from the beginning" 34 According to Westerners, they will create bloody breaches in the civilization order in the European space, both distressing and unacceptable to Muslims, with the clear purpose of instilling fear and disrupting the „bonoma” of Western daily life. In support of this view, one starts from the finding that „Muslims are involved in more violence between groups than those belonging to other civilizations?" 35 , which fuels the dilemma of the European world regarding the compatibility of the values to which the Islamic world relates to the Christian values, for which freedom represents the supreme wealth of the human being.

The realities of the last years show us a Western Europe in which the phenomenon of crime has experienced alarming quotas, at the origin of many of the antisocial activities being migrants, some even to the third generation, not integrated in the family or in the society, with a confused religious identity determined by leaving the places to which they are linked with their identity, with serious behavioral problems related to self-control and anger, with problematic personality that irreparably marks their feelings, inner experiences or evolution and which determines that their personal opinions be imposed by threat or violence of the members of the communities to which they belong, assuming consciously the illegal character of the actions taken. ${ }^{36}$

The reactions of public opinion and extremist political forces, to the unprecedented manifestation of the phenomena associated with crime in which migrants from the Middle East are involved, are prompt and seem to concern the national authorities of Western European states themselves. Extreme right-wing groups are gaining increasing popularity in the context of claiming an anti-immigration public position, the main themes being the "Islamization" of European society and the loss of national identity, and the common denominator of the approaches is radicalization, the hatred against Islamists, holding the absolute truth" in terms of solving the refugee problem and the desire to "restore order" including extreme measures. Against this background, far-right and nationalist parties such as the Alternative for Germany, Germany, the National Front/National Assembly from France, VOX in Spain, Sweden Democrats, Golden Dawn in Greece, Law and Justice in Poland, The Freedom Party in the Netherlands and the Danish People's Party have recorded a decline in popularity and electoral success. ${ }^{37}$

We can therefore conclude that a new wave of refugees from the Middle East to western Europe will affect the continent's security, on multiple levels, the consequences being unforeseeable. In the field of knowledge, prevention and countering the threats

\footnotetext{
${ }^{34}$ Samuel, Huntington, Clash of Civilizations and the Restoration of the World Order, 392

${ }^{35}$ Samuel, Huntington, Clash of Civilizations and the Restoration of the World Order, 391

${ }^{36}$ Cătălin, Peptan, Terrorism. Events and developments in the hot areas of the world..., 37.

${ }^{37} \mathrm{https} / / /$ monitorulapararii.ro/extrema-dreapta-europeana-dominata-de-lone-wolfs-si-radicalizarea-online-125424/ accessed 09.03.2020
} 
potentiated by the phenomenon of migration, a special role belongs to the intelligence structures of the affected European states, which must develop their capabilities for capturing and processing information and diversify their forms of international cooperation, within NATO or the European Union, based on the needs to value the experience, expertise and capabilities of the partners ${ }^{38}$, by providing relevant information on the dynamics of the evolution of risk factors and threats to regional security in the fields related to the phenomenon of migration. The European leadership will have to integrate into the values of a secular, Euro-Atlantic society, indoctrinated religious populations, with little chance of success if we refer only to the specificities of the Islamic world.

${ }^{38}$ Cătălin, Peptan, Information and intelligence in security equation, Annals of the „Constantin Brâncuși” of Târgu Jiu, Letter ans Social Science, Series2/2019, 39-45. 


\section{REFERENCES}

1. Ehteshami, Anoushiravan, Globalization and Geopolitics in the Middle East Old Games, New Rules, Routledge, London, 2007.

2. Gavriluță, Carmen, Revolt of the Orient, Polirom Publishing House, Iași, 2013.

3. Huntington, Samuel P, Clash of civilizations and the restoration of world order, Litera Publishing House, Bucharest, 2019.

4. Lamy, Pascal, Gnesotto, Nicole, Baer, Jean-Michel, Where is the world going ?, Niculescu Publishing House, Bucharest, 2018.

5. Mansfield, Peter, A History of the Middle East, Humanitas Publishing House, Bucharest, 2015.

6. Peptan, Cătălin, Terrorism. Events and developments in the hot areas of the world. Middle East. Asia. Africa, "Brâncuși" Academic Publishing House Târgu Jiu, 2019.

7. Peptan Cătălin, Information and intelligence in security equation, Annals of the "Constantin Brancusi" of Târgu Jiu, Letter ans Social Science, Series2 / 2019, pp. 39-45.

8. Tasgin, Serkan, Cam, Taner, Reasons for Terrorism in the Middle East, in Alexander R. Dawoody (editor), Eradicating Terrorism from the Middle East Policy and Administrative Approaches, Springer, 2016.

9. Flavius Cristian Marcau, Mihaela Andreea Ciorei, "The vision about international security at the biggining of the XXI century", in European Scientific Journal, april 2013 edition vol.9, no.11, 301-311.

10. Flavius Cristian Mărcău, Mihaela Andreea Ciorei, "The role of intelligence in the fight against terror," in European Scientific Journal, IX (2013), no. 2, p. 1-11.

11. Temelcura, Ece, Turkey, between madness and melancholy, Corint Books, Bucharest, 2017.

12. https://www.ziare.com/international/statul-islamic/2017-anul-prabusirii-califatului-statului-islamic1495057.

13. https://www.adevarul.ro/international/in-lume/statului-islamic-ras-fata-pamantului-siria1_5c95ec51445219c57e9038d4/index.html.

14. https://www.trt.net.tr/romana/programe/2019/07/30/turcia-si-migratia-ieri-astazi-maine-1245110.

15. https://www.dw.com/ro/în-drum-spre-un-nou-război-ruso-turc/a-52574097/ https://www.dw.com/ro/reuniune-extraordinară-nato-după-escaladarea-situaţiei-din-siria/a-52572751.

16. https://www.dw.com/ro/reuniune-extraordinară-nato-după-escaladarea-situaţiei-din-siria/a-52572751.

17. https://www.dw.com/ro/comentariu-joc-de-putere-în-jurul-susținătorilor-isis-repatriați/a-51213795.

18. https://www.digi24.ro/stiri/actualitate/turcia-sustine-ca-a-lasat-75-000-de-migranti-sa-treaca-frontieracu-ue-harta-cu-traseul-refugiatilor-care-trece-prin-mijlocul-romaniei-1268534.

19. https://www.english.alarabiya.net/en/media/television-and-radio/2020/02/29/Turkish-state-ownedTRT-Arabic-posts-map-showing-refugees-path-toFrance.html?fbclid=IwAR3uEyzE4WhiN4teDjgItlgg0HYCcXbhxFPDB0WAjmYPmowbRzE36jjMR5 $\mathrm{M} /$.

20. https://www.dw.com/ro/criza-refugiaţilor-în-grecia-situaţia-se-agravează-pelesbos/a-52605453.

21. https://24-ore.ro/2020/03/02/angela-merkel-declara-ca-este-inacceptabil-ca-turcia-sa-faca-presiuniasupra-ue-pe-spatele-refugiatilor.

22. https://www.news.ro/externe/franta-deplin-solidara-cu-grecia-si-bulgaria-afirma-macron-care-vrea-sase-evite-o-criza-umanitara-si-a-migratiei-in-urma-unui-aflux-de-migranti-din-turcia922401302002020031319286947.

23. https://www.dw.com/ro/criza-refugiaţilor-în-grecia-situaţia-se-agravează-pelesbos/a-52605453.

24. https://www.europarl.europa.eu/doceo/document/CRE-9-2020-02-12-INT-3-564-0000_RO.

25. https://www.business24.ro/articole/forta+munca+turcia.

26. https://monitorulapararii.ro/extrema-dreapta-europeana-dominata-de-lone-wolfs-si-radicalizareaonline-1-25424. 